\title{
Distribution and number of cultured bacteria of the phosphorus cycle in the ecosystem of Lake Baikal
}

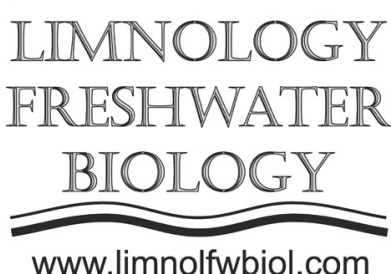

\author{
Suslova M.Yu., Sukhanova E.V., Shtykova Yu.R., Podlesnaya G.V., \\ Galachyants A.D., Zimens E.A., Belykh O.I.
}

Limnological Institute, Siberian Branch of the Russian Academy of Sciences, Ulan-Batorskaya Str., 3, Irkutsk, 664033, Russia

\begin{abstract}
The study of cultured bacteria of the phosphorus cycle in biotopes of Lake Baikal (water column, surface microlayer of water, epilithic biofilms and bottom sediments) revealed uneven distribution over areas, biotopes and groups of microorganisms. Therefore, in biofilms and water column, phosphatase active bacteria prevail over phosphate solubilizing bacteria on average by an order of magnitude, whereas in the bottom sediments, their number is comparable. In the bottom sediments of the southern basin of the lake (the Selenga shallow waters), the number of bacteria of the phosphorus cycle $\left(1461 \mathrm{CFU} / \mathrm{cm}^{3}\right)$ is three times higher than in the northern part $\left(463 \mathrm{CFU} / \mathrm{cm}^{3}\right)$. The maximum number of phosphatase active bacteria was detected in epilithic biofilms, $39251 \mathrm{CFU} /$ $\mathrm{cm}^{3}$, and the minimum number was in the water column, $65 \mathrm{CFU} / \mathrm{cm}^{3}$. Phosphate solubilizing bacteria numerically prevail in the bottom sediments $\left(915 \mathrm{CFU} / \mathrm{cm}^{3}\right)$ and biofilms $\left(900 \mathrm{CFU} / \mathrm{cm}^{3}\right)$; the minimum number is typical of the water column $\left(2 \mathrm{CFU} / \mathrm{cm}^{3}\right)$. The occurrence of phosphate solubilizing bacteria in the studied biotopes varied from $46 \%$ to $97 \%$, with a $100 \%$ occurrence of phosphatase active bacteria.
\end{abstract}

Keywords: Lake Baikal, phosphorus, cultured bacteria, neuston, epilithic biofilm, bottom sediments.

\section{Introduction}

Industrial and domestic wastewater pose the greatest threat to Lake Baikal. The influx of nutrients, including phosphorus, contributes to eutrophication of the lake waters. In water bodies, phosphorus presents in the form of inorganic and organic compounds. In the water, there are small amounts of phosphorus in the form of phosphate ion, from 5 to $17 \mu \mathrm{g} / \mathrm{l}$ (Khodzher et al., 2017), because it is rapidly used by aquatic organisms or pass into slightly soluble or insoluble forms that precipitate. Its reserves in an aquatic ecosystem are mainly found in the organic form (phytoand zooplankton). Microorganisms release phosphorus from dead organisms, and it is again involved in the biological cycle. During the study of microbial processes of phosphorus cycles, two bacterial groups were investigated: 1 ) phosphatase active bacteria (PAB) and 2) bacteria dissolving mineral sparingly soluble phosphates, phosphate solubilizing bacteria (PSB).

Microbial processes are very important in the phosphorus cycle, because no transformation reaction of phosphate-containing substances occurs spontaneously.

\section{Materials and methods}

The presence and number of $\mathrm{PAB}$ were determined among organotrophic bacteria grown on fish-peptone agar (FPA:10) by the number of colonies stained with phenolphthalein (Rodina, 1965). The number of PSB was determined on the medium with insoluble mineral phosphate, $\mathrm{Ca}_{3}\left(\mathrm{HPO}_{4}\right)_{2}$, revealing active colonies by the presence of a clarification zone (Suslova et al., 2018).

Study objects were water from abyssal and littoral zones of the lake, surface microlayer of water, neuston $(\mathrm{N})$, bottom sediments, and epilithic biofilms (EB) collected from the surface of stones in the littoral zone of Lake Baikal. Deepwater samples were taken in May, June and September 2018 and 2019 from the surface to the bottom at the standard transects of Lake Baikal: the Marituy settlement - the Solzan settlement, the Listvyanka settlement - the Tankhoy settlement: Ukhan Cape - Tonky Island, Khoboy Cape - Krestovy Cape; Elokhin Cape - the Davsha settlement, the Baikalskoye settlement - Turali Cape. The bottom sediment samples were collected in October 2018 at a distance of 0.5 and $1 \mathrm{~km}$ from the coast near the Selenga shallow waters (12 samples) as well as in the northern part of the lake: from Kotelnikovsky Cape to Gydanskaya Firth (15 samples). Samples of epilithic biofilm, neuston, and water column were studied in the littoral zone of the lake in August 2018 and 2019 near the Listvyanka settlement, the Bolshiye Koty settlement, the Bolshoye Goloustnoye settlement, Aya Bay, Malyie Olkhonskiye Vorota Strait, and Izhimey Cape. 
Table. Number of cultured PAB and PSB in biotopes of Lake Baikal in 2018-2019

\begin{tabular}{|c|c|c|c|c|c|c|c|}
\hline \multirow[t]{2}{*}{$\begin{array}{l}\text { Biotope, } \\
\text { unit of mea- } \\
\text { surement }\end{array}$} & \multirow[t]{2}{*}{ Month } & \multicolumn{2}{|c|}{$\begin{array}{l}\text { The PAB number } \\
\text { value limits } \\
\text { average }\end{array}$} & \multirow[t]{2}{*}{ Average } & \multicolumn{2}{|c|}{$\begin{array}{l}\text { The PSB number } \\
\frac{\text { value limits }}{\text { average }}\end{array}$} & \multirow[t]{2}{*}{$\begin{array}{l}\text { Aver- } \\
\text { age }\end{array}$} \\
\hline & & 2018 & 2019 & & 2018 & 2019 & \\
\hline $\begin{array}{l}\text { Neuston, } \\
\text { CFU/cm }{ }^{3}\end{array}$ & August & $\frac{1100-2200}{1535}$ & $\frac{100-1800}{766}$ & 1151 & $\frac{130-500}{284}$ & $\frac{1-1428}{239.2}$ & 262 \\
\hline \multirow{3}{*}{$\begin{array}{l}\text { Water column, } \\
\mathrm{CFU} / \mathrm{cm}^{3}\end{array}$} & June & $\frac{2-20}{13.8}$ & $\frac{2-700}{116.7}$ & 65 & $\frac{0-20}{4.7}$ & $\frac{0-12.5}{2.5}$ & 4 \\
\hline & $\begin{array}{c}\text { August } \\
\text { (littoral } \\
\text { zone) } \\
\end{array}$ & $\frac{2-168}{20.8}$ & $\frac{2-68}{16.3}$ & 19 & $\frac{0-6}{1.1}$ & $\frac{0-9}{1.8}$ & 2 \\
\hline & September & $\frac{1-200}{40.6}$ & $\frac{22-480}{178.6}$ & 110 & $\frac{0-4.7}{1}$ & $\frac{0-18}{2.9}$ & 2 \\
\hline $\begin{array}{l}\text { Epilithic } \\
\text { biofilm, } \\
\mathrm{CFU} / \mathrm{cm}^{3}\end{array}$ & August & $\frac{5000-100000}{25530.3}$ & $\frac{2000-600000}{52980}$ & 39251 & $\frac{200-1400}{780.6}$ & $\frac{100-10080}{1020.2}$ & 900 \\
\hline $\begin{array}{c}\text { Bottom sedi- } \\
\text { ments, } \\
\mathrm{CFU} / \mathrm{cm}^{3} \\
\end{array}$ & September & $\frac{100-2950}{906.5}$ & $\mathrm{n} / \mathrm{a}$ & 907 & $\frac{10-2600}{914.5}$ & $\mathrm{n} / \mathrm{a}$ & 915 \\
\hline
\end{tabular}

\section{Results and discussion}

In the water from the abyssal zone of the lake, the PAB number was 30 times higher than the PSB number. In 2018, the PAB number was from 2 to $200 \mathrm{CFU} / \mathrm{cm}^{3}$ (Table). In 2019, it became on average six times higher than in 2018, and in some samples, it reached $700 \mathrm{CFU} /$ $\mathrm{cm}^{3}$ (Table). High PAB number in 2019 was detected in the southern basin of the lake in May at depths of $10 \mathrm{~m}$ and $50 \mathrm{~m}$ (700 and $450 \mathrm{CFU} / \mathrm{cm}^{3}$, respectively), which is likely due to the development of the spring phytoplankton under the ice, and in September (239 $\mathrm{CFU} / \mathrm{cm}^{3}$ ) (Table). In the central and northern parts of the lake, the PAB number was 131 and 142 CFU/ $\mathrm{cm}^{3}$, respectively. In the surface water (up to $5 \mathrm{~m}$ ), the PAB number was lower than in deep water. Most likely, this is due to the dominance of phosphatase active cyanobacteria in this ecological niche. The PSB number throughout the water area was low and did not exceed $20 \mathrm{CFU} / \mathrm{cm}^{3}$, and the spatial distribution in different seasons and years was uneven. In 2018, PSB were detected in $88 \%$ of samples in May as well as in $64 \%$ of samples in September. In 2019, this group was detected in $97 \%$ of samples in the same months. PAB were found in all water samples.

In the bottom sediments, the numbers of $\mathrm{PAB}$ and PSB were comparable and did not have significant differences. Near the Selenga shallow waters, the number of the investigated groups was three times higher than in the northern part of the lake. Therefore, in the bottom sediments opposite the Selenga River delta, the numbers of PAB and PSB averaged 1481 and1441 $\mathrm{CFU} / \mathrm{cm}^{3}$, respectively, and in the northern part- 454 and $472 \mathrm{CFU} / \mathrm{cm}^{3}$ (Table).

In August 2018-2019, the PAB number in biofilms and water column was higher than the PSB number, and it was maximum in 2019 in EB, $600000 \mathrm{CFU} / \mathrm{cm}^{3}$ (Table). The obtained results were comparable with our previous data (Suslova et al., 2018). The PSB number in EB and bottom sediments averaged 900 and 914 CFU/ $\mathrm{cm}^{3}$, respectively, which is three times higher than in $\mathrm{N}$ (Table). In the $\mathrm{N}$ samples, the PAB number was two times higher in 2018 than in 2019. The PSB number was comparable and averaged $262 \mathrm{CFU} / \mathrm{cm}^{3}$ (Table). In $\mathrm{N}$ and $\mathrm{EB}, \mathrm{PAB}$ were detected in all samples during the entire study period. In 2018, PSB were detected in 55\% of $\mathrm{N}$ samples and $46 \%$ of EB samples. In 2019, PSB were detected in $70 \%$ and $76 \%$ of samples, respectively.

\section{Conclusions}

In the Baikal microbial communities of biofilms and water column, we identified the trend of the higher number of phosphatase active bacteria compared to phosphate solubilizing bacteria on average by an order of magnitude, whereas in the bottom sediments, these groups were numerically equal. The occurrence of PSB in the studied biotopes varied from 46 to $97 \%$, with a $100 \%$ occurrence of PAB. The maximum number of $\mathrm{PAB}$ was detected in epilithic biofilms and minimum number - in the water column. PCB numerically prevailed in the bottom sediments and biofilms, and the minimum was detected in the water column. 


\section{Acknowledgements}

The study was carried out within the framework of State Task No. 0345-2019-0003 «Microbial and viral communities in biofilms...». The authors thank R. Gnatovsky, V. Blinov, V. Ivanov, I. Nebesnykh, Yu. Yushchuk for their assistance in water sampling. This work was supported by RFBR grant no.18-54-05005_ arm_a.

\section{References}

Khodzher T.V., Domysheva V.M., Sorokovikova L.M. et al. 2017. Current chemical composition of Lake Baikal water. Inland Waters 7(3): 250-258. DOI: 10.1080/20442041.2017.1329982

Rodina A.G. 1965. Metody vodnoj mikrobiologii: prakticheskoe rukovodstvo [Methods of water microbiology. Practical guidance]. Moscow-Leningrad: Nauka. (in Russian)

Suslova M.Yu., Pestunova O.S., Sukhanova E.V. et al. 2018. Role of cultured microorganisms from biofilms formed on rocky substrates in the Lake Baikal self-purification system. Microbiology 87: 817-824. DOI: 10.1134/ S0026261718060176 